\title{
Effect of Saccharomyces cerevisiae cells immobilisation on mead production
}

\author{
A.P. Pereira ${ }^{\text {a,b }}$, A. Mendes-Ferreira ${ }^{\text {a }}$, J.M. Oliveira ${ }^{c}$, L.M. Estevinho ${ }^{\text {b, }}$, A. Mendes-Faia ${ }^{\mathrm{a}, * *}$ \\ ${ }^{a}$ IBB-Institute for Biotechnology and Bioengineering, Centre of Genomics and Biotechnology, Universidade de Trás-os-Montes e Alto Douro, Apartado 1013, \\ 5001-801 Vila Real, Portugal

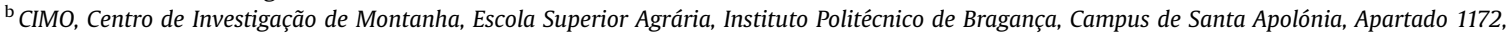 \\ 5301-855 Bragança, Portugal \\ ${ }^{\mathrm{C}}$ IBB-Institute for Biotechnology and Bioengineering, Centre of Biological Engineering, Universidade do Minho, 4710-057 Braga, Portugal
}

\section{A R T I C L E I N F O}

\section{Article history:}

Received 9 July 2013

Received in revised form

31 October 2013

Accepted 2 November 2013

\section{Keywords:}

Alcoholic fermentation

Aroma profile

Honey

Mead

Yeast immobilisation

\begin{abstract}
A B S T R A C T
Mead is a traditional alcoholic beverage obtained by the fermentation of diluted honey performed by yeasts. In this work the potential of application of immobilised yeast cells on single-layer Ca-alginate or double-layer alginate-chitosan for mead production was assessed for the first time. The meads produced either with entrapped or free cells were evaluated in terms of quality and aroma profile. The immobilisation procedure had no adverse effect on cell viability, since minor differences were found in fermentation kinetics among the strains and immobilisation systems. The double-layer alginate-chitosan had no advantage compared with the single-layer Ca-alginate, as the number of free cells in the medium, resulting from cell leakage, was similar. Although meads obtained with entrapped yeast cells presented less ethanol and glycerol and more acetic acid, it exhibited larger amounts of volatile compounds. Immobilised cells produced meads with more compounds with fruity characteristics, such as ethyl octanoate and ethyl hexanoate; however the concentrations of undesirable compounds in such meads were also higher. The effect of immobilisation on the aroma profile was important, but the strain contribution was also of major importance. Thus, the sensory analysis of final product gives an important insight on the overall quality.
\end{abstract}

(c) 2013 Published by Elsevier Ltd.

\section{Introduction}

Mead is a traditional honey-derived beverage containing 8 $18 \%(\mathrm{v} / \mathrm{v})$ ethanol. The beverage is produced by yeast alcoholic fermentation of diluted honey (Mendes-Ferreira et al., 2010; Ramalhosa, Gomes, Pereira, Dias, \& Estevinho, 2011). Honey production is a significant economic activity in European countries, however to the development of honey-derived, such as mead, is of extreme importance to increase the profit of the beekeeping industry. Mead fermentation progress depends on several factors, such as yeast strain (Pereira, Mendes-Ferreira, Oliveira, Estevinho, \& Mendes-Faia, 2013), honey type and composition (Navrátil, Šturdík, \& Gemeiner, 2001), lack of essential nutrients such as a deficiency in available nitrogen (Mendes-Ferreira et al., 2010), low mineral concentration, low pH

\footnotetext{
* Corresponding author. Tel.: +351 273303342; fax: +351 273325405.

** Corresponding author. Tel.: +351 259350554; fax: +351 259350480

E-mail addresses: leticia@ipb.pt (L.M. Estevinho), afaia@utad.pt (A. MendesFaia).
}

(Sroka \& Tuszyński, 2007) and low buffer capacity (Maugenet, 1964). Several strategies have been introduced for the optimisation of mead fermentation through the use of an appropriate honey-must formulation to improve the alcoholic fermentation performance of yeast (Mendes-Ferreira et al., 2010), using starter yeast cultures isolated from honey/honey-wine (Pereira, Dias, Andrade, Ramalhosa, \& Estevinho, 2009; Teramoto, Sato, \& Ueda, 2005) or commercial yeast starter cultures (Koguchi, Saigusa, \& Teramoto, 2009; Navrátil et al., 2001; Sroka \& Tuszyński, 2007). It has been shown that supplementation of honey-must with ammonium significantly reduces fermentation length (Mendes-Ferreira et al., 2010). However, some residual sugars, other than glucose, still remain in meads after alcoholic fermentations despite the initial nitrogen concentration or the yeast strain used (Mendes-Ferreira et al., 2010). Recently, we have shown that increasing pitching rate impacts yeast fermentative activity, and significant time was saved in the fermentation process, with no detrimental impact on mead aroma composition (Pereira et al., 2013).

Microorganism immobilisation methods have gained attention in the last few decades and are being successfully applied in the 
production of alcohols (ethanol, butanol and isopropanol), organic acids (malic, citric, lactic and gluconic acids), enzymes (cellulose, amylase and lipase), the biotransformation of steroids for wastewater treatment and food applications (beer and wine) (Liouni, Drichoutis, \& Nerantzis, 2008; Reddy, Reddy, Reddy, \& Reddy, 2008), among others. Despite the great potential, the industrial use of immobilised cells is still limited because further application depends on the development of immobilisation procedures that can be readily scaled up (Kourkoutas, Bekatorou, Banat, Marchant, \& Koutinas, 2004). The main techniques that enable biomass confinement are attachment or adsorption on solid carrier surfaces, entrapment within a porous matrix, self-aggregation of cells (flocculation) and cell containment behind a barrier (Pilkington, Margaritis, Mensour, \& Russel, 1998). Entrapment involves imprisoning living cells within a rigid network that permits the diffusion of substrates and products, thereby making possible the growth and maintenance of active cells (Diviès \& Cachon, 2005). The polymeric beads are usually spherical, with diameters ranging from 0.3 to $3 \mathrm{~mm}$ (Verbelen, De Schutter, Delvaux, Verstrepen, \& Delvaux, 2006). Owing to the very gentle, simple and rapid procedure, the entrapment of cells in alginate hydrogels is still the most frequently used method for immobilisation (Pajic-Lijakovic, Plavsic, Nedovic, \& Bugarski, 2010).

The immobilised microbial cells in a hydrogel matrix are protected from harsh environmental conditions such as $\mathrm{pH}$, temperature, organic solvent and inhibitors (Kocher, Kalra, \& Phutela, 2006; Park \& Chang, 2000). Cell growth in the porous matrix depends on diffusion limitations imposed by the porosity of the material and later by the impact of accumulating biomass (Kourkoutas et al., 2004). Cell immobilisation also allows easier handling of the cells and facilitates the clarification of the final product (Kocher et al., 2006; Kostov, Angelov, Mihaylov, \& Poncelet, 2010; Kourkoutas et al., 2004; Park \& Chang, 2000). Studies with immobilised cells in Ca-alginate (Qureshi \& Tamhane, 1986) or pectate (Navrátil et al., 2001) in mead production have showed that fermentation length was reduced or fermentation rate increased, respectively. Therefore, the purpose of this study was to evaluate the effect of the yeast cell immobilisation of two yeast strains (QA23 and ICV D47) in a fed-batch system. The fermentation profile, cell viability, mead composition and mead aroma profile were evaluated in meads fermented with free or immobilised cells. Yeast cell immobilisation was accomplished using alginate high molecular hydrophilic polymeric gel at a concentration of $4 \%$. In addition, single (Ca-alginate) or double layers (alginate-chitosan) were tested. The cells were entrapped in the gel using a drop-forming procedure.

\section{Materials and methods}

\subsection{Yeast strains}

Saccharomyces cerevisiae Lalvin QA23 (Lallemand, Montreal, Canada) and S. cerevisiae Lalvin ICV D47 (Lallemand, Montreal, Canada) were used in this study as active wine dry yeasts.

\subsection{Honey}

A dark multifloral honey was used that was derived primarily from the pollen of Castanea spp. and Erica spp. and was purchased from a local beekeeper in the northeastern region of Portugal. The characteristics and satisfactory quality of the honey were assured in accordance with the requirements established in Portuguese law (Decreto-Lei $n^{\circ}$ 214/2003, 18th September).

\subsection{Preparation of honey-must for fermentation}

The honey-must for fermentation with free or immobilised cells was prepared as described by Pereira et al. (2013). The honey was diluted in natural commercially obtained spring water purchased in the market $(37 \% \mathrm{w} / \mathrm{v})$ to achieve $23^{\circ} \mathrm{Brix}$, corresponding to an alcoholic beverage with approximately $13.5 \%$ ethanol and mixed to homogeneity. Then, the insoluble materials were removed from the mixture by centrifugation $(2682 \times g$ for $30 \mathrm{~min}$; Eppendorf $5810 \mathrm{R}$ centrifuge) to obtain a clarified honey-must. Titratable acidity was adjusted with $5 \mathrm{~g} / \mathrm{L}$ of potassium tartrate (Sigma-Aldrich, St. Louis, USA), and pH was adjusted to 3.7 with malic acid (Merck, Darmstadt, Germany). The nitrogen content was adjusted to $267 \mathrm{mg} / \mathrm{L}$ with diammonium phosphate (DAP, BDH Prolabo, Leuven, Belgium). The parameters ${ }^{\circ}$ Brix (Optic Ivymen System, ABBE Refractometer), pH (Five Easy FE20, Mettler-Toledo), titratable acidity and assimilable nitrogen concentration were determined prior to and after the adjustments. Titratable acidity was determined according to standard methods (Organisation Internationale de la Vigne et du Vin, 2006). Yeast assimilable nitrogen (YAN) was determined by the formaldehyde method as previously described (Aerny, 1996). After clarification, $10 \mathrm{~mL}$ of the sample was transferred into a $50-\mathrm{mL}$ beaker and diluted with $15 \mathrm{~mL}$ of water. The $\mathrm{pH}$ was adjusted to 8.1 with $100 \mathrm{mM} \mathrm{NaOH}$ (Merck, Darmstadt, Germany) and $2.5 \mathrm{~mL}$ of formaldehyde (Merck, Darmstadt, Germany) at $\mathrm{pH} 8.1$ was added. After $5 \mathrm{~min}$, the $\mathrm{pH}$ was adjusted again to 8.1 by titration with $50 \mathrm{mM} \mathrm{NaOH}$. Assimilable nitrogen was calculated using the following formula:

$$
\begin{aligned}
\text { YAN }(\mathrm{mg} / \mathrm{L})= & {[(\text { vol. } \mathrm{NaOH}) \times(\text { conc. } \mathrm{NaOH}) \times 14} \\
& \times 1000] /(\text { sample volume })
\end{aligned}
$$

The honey-must was pasteurised at $65{ }^{\circ} \mathrm{C}$ for $10 \mathrm{~min}$ and then immediately cooled. No sulphur dioxide was added to the honeymust.

\subsection{Immobilisation of yeast cells}

Starter cultures were prepared by the rehydration of $2 \mathrm{~g}$ of active dry yeast in $20 \mathrm{~mL}$ of sterilised water at $38{ }^{\circ} \mathrm{C}$, according to the manufacturer's instructions, to obtain ca. $10^{8} \mathrm{CFUs} / \mathrm{mL}$. Sodium alginate (BDH Prolabo, Leuven, Belgium) was dissolved in distilled water at concentrations of $4 \%(\mathrm{w} / \mathrm{v})$ and sterilised by autoclaving at $121^{\circ} \mathrm{C}$ for $20 \mathrm{~min}$.

To inoculate the honey-must with $10^{6} \mathrm{CFU} / \mathrm{mL}$, the appropriate amount of yeast suspension was added to $10 \mathrm{~mL}$ of sodium alginate solution. The polymer-cell mixture was added dropwise to a $180 \mathrm{mM} \mathrm{CaCl}_{2}$ (Panreac, Barcelona, Spain) sterilised solution and left to harden in this solution for $30 \mathrm{~min}$ at $4{ }^{\circ} \mathrm{C}$. Single-layer $S$. cerevisiae immobilised beads were rinsed three times with sterile distilled water. Then, the immobilised beads were transferred into the honey-must.

For double-layer immobilisation, after the cells were left to harden in $\mathrm{CaCl}_{2}$ solution for $30 \mathrm{~min}$ at $4{ }^{\circ} \mathrm{C}$, the beads were decanted and added to a chitosan (Sigma-Aldrich, St. Louis, USA) solution prepared according to Liouni et al. (2008) and maintained at $25{ }^{\circ} \mathrm{C}$ for $24 \mathrm{~h}$ at a rotational speed of $80 \mathrm{~min}^{-1}$. Double-layer S. cerevisiae immobilised beads were decanted, rinsed three times with autoclaved distilled water and transferred into the honeymust.

\subsection{Fermentation conditions and monitoring}

The immobilised beads in the single and double layers were transferred into the honey-must for fed-batch fermentations. In 
parallel, free-cell fermentations with $S$. cerevisiae strain QA23 or ICV D47 were performed with $10^{6} \mathrm{CFU} / \mathrm{mL}$ for comparison with immobilised systems. All fermentations were conducted in triplicate using a previously described system (Mendes-Ferreira et al., 2010) that consisted of $250 \mathrm{~mL}$ flasks filled to two thirds of their volume and fitted with a side-arm port sealed with a rubber septum for anaerobic sampling. The flasks were maintained during alcoholic fermentation at $25{ }^{\circ} \mathrm{C}$ under permanent but moderate shaking $(120 \mathrm{rpm})$, which mimicked the real industrial environment. Aseptic sampling for monitoring fermentation was performed using a syringe-type system as previously described (Mendes-Ferreira, Barbosa, Falco, Leão, \& Mendes-Faia, 2009). The weight losses of the fermentations were monitored daily as an estimate of $\mathrm{CO}_{2}$ production. To determine the growth parameters in the free system and of the suspended cells in the medium, samples were collected and appropriately diluted for the measurement of their optical density at $640 \mathrm{~nm}$ in a UV-visible spectrometer (Unicam Helios) and for counting their CFUs in solid yeast peptone dextrose agar (YPD - $20 \mathrm{~g} / \mathrm{L}$ glucose, $10 \mathrm{~g} / \mathrm{L}$ peptone, $5 \mathrm{~g} / \mathrm{L}$ yeast extract and $20 \mathrm{~g} / \mathrm{L}$ agar) plates after incubation at $25^{\circ} \mathrm{C}$ for $48 \mathrm{~h}$. Determinations of reducing sugars, prior to inoculation and during fermentation, were performed using the 3,5-dinitrosalicylic acid (DNS) method with glucose as the standard. At the end of alcoholic fermentation, samples were taken from all fermented media for several analytical and aroma profile determinations.

\subsection{Analyses performed at the end of fermentation}

Free and immobilised cell concentrations were determined as cell dry weight. The culture dry weight of the suspended cells in the medium (from the free and immobilised systems) was determined from triplicate samples of $14 \mathrm{~mL}$ that were centrifuged in preweighed tubes at $3890.1 \times \mathrm{g}$ for $10 \mathrm{~min}$, washed twice with sterile deionised water, dried for $24 \mathrm{~h}$ at $100{ }^{\circ} \mathrm{C}$ and stored in a desiccator before weighing.

For determination of dry weight, immobilisation yield and concentration of viable cells immobilised in single and double layers, the beads were liquefied using a chemical method, according a procedure adapted from Göksungur and Zorlu (2001). Fifty beads were washed with water and dissolved in $50 \mathrm{~mL}$ of a $50 \mathrm{mM}$ sterilised sodium citrate (Merck, Darmstadt, Germany) solution with continuous stirring for $30 \mathrm{~min}$ at room temperature. The dry weight of immobilised cells was determined by the same procedure described previously for the free cell system. For assessing the growth of immobilised cells, after appropriate dilutions of liquefied beads, the number of CFUs in solid YPD plates was counted after incubation at $25{ }^{\circ} \mathrm{C}$ for $48 \mathrm{~h}$. The immobilisation yield was calculated as the immobilised dry weight of yeasts/immobilised and free dry weight of yeasts $\times 100$ (Inal \& Yiğitoğlu, 2011).

The oenological parameters, such as total sulphur dioxide $\left(\mathrm{SO}_{2}\right)$, $\mathrm{pH}$, titratable acidity, volatile acidity and ethanol content, were determined according to standard methods (Organisation Internationale de la Vigne et du Vin, 2006). Yeast assimilable nitrogen (YAN) was determined by the formaldehyde method as previously described (Aerny, 1996).

\subsection{Determination of glucose, fructose, glycerol, acetic acid and ethanol}

Glucose, fructose, ethanol, glycerol and acetic acid were individually analysed, using a Varian high performance liquid chromatography (HPLC) system, equipped with a Rheodyne injector with a $20-\mu \mathrm{L}$ loop, a Supelco Gel C-610 H column $(300 \mathrm{~mm} \times 7.8 \mathrm{~mm})$ at $35^{\circ} \mathrm{C}$ and a refractive index detector RI-4 (Varian). Isocratic elution was employed with a mobile phase consisting of $0.1 \%(\mathrm{v} / \mathrm{v})$ phosphoric acid (Panreac, Barcelona, Spain) at a flow rate of $0.5 \mathrm{~mL} / \mathrm{min}$. Data were recorded and integrated using Star Chromatography Workstation software (Varian). Glucose, fructose, ethanol, glycerol and acetic acid were quantified by external standard calibration.

\subsection{Analysis of mead aromatic compounds}

Mead produced with different immobilisation systems and the free cell system was analysed for major volatile compounds by GCFID and for minor volatile compounds by GC-MS. The major compounds in the samples were determined directly by the internal standard (4-nonanol) method, taking into account the relative response of the detector for each analyte. Identification was achieved by a comparison of retention times with those of pure standard compounds. The minor volatile compounds were analysed after extraction with dichloromethane and quantified as 4-nonanol equivalents. Identification was achieved by a comparison of retention indices and mass spectra with those of pure standard compounds.

\subsubsection{Chromatographic analysis of major volatile compounds}

In a glass tube, $100 \mu \mathrm{L}$ of an ethanolic solution with $3640 \mathrm{mg} / \mathrm{L}$ of internal standard (4-nonanol, Merck, Darmstadt, Germany) was added to $5 \mathrm{~mL}$ of mead.

A Chrompack GC CP-9000 gas chromatograph equipped with a split/splitless injector, a flame ionisation detector (FID) and a capillary column CP-Wax $57 \mathrm{CB}(50 \mathrm{~m} \times 0.25 \mathrm{~mm} ; 0.2 \mu \mathrm{m}$ film thickness) was used. The temperatures of the injector and detector were both set to $250{ }^{\circ} \mathrm{C}$, and the split ratio was $15 \mathrm{~mL} / \mathrm{min}$. The column temperature was initially held at $60{ }^{\circ} \mathrm{C}$ for $5 \mathrm{~min}$, then programmed to rise from $60{ }^{\circ} \mathrm{C}$ to $220^{\circ} \mathrm{C}$ at $3{ }^{\circ} \mathrm{C} \mathrm{min}-1$ and finally maintained at $220^{\circ} \mathrm{C}$ for $10 \mathrm{~min}$. The carrier gas was special helium $4 \times$ (Praxair) at a flow rate of $1 \mathrm{~mL} / \mathrm{min}$ ( $125 \mathrm{kPa}$ at the head of the column). The analysis was performed by the injection of $1 \mu \mathrm{L}$ of sample. The quantification of volatile compounds, after the determination of the detector response factor for each analyte, was performed with Star-Chromatography Workstation software, version 6.41 (Varian) by comparing test compound retention times with those of pure standard compounds.

\subsubsection{Extraction of volatiles}

The extraction of mead minor volatiles was performed according to the method described by Oliveira, Faria, Sá, Barros, and Araújo (2006). In a 10-mL culture tube (Pyrex, ref. 1636/26MP), $8 \mathrm{~mL}$ of mead clarified by centrifugation, $80 \mu \mathrm{L}$ of an ethanolic solution, $36.4 \mathrm{mg} / \mathrm{L}$ of an internal standard (4-nonanol, Merck, Darmstadt, Germany) and a magnetic stir bar (22.2 $\mathrm{mm} \times 4.8 \mathrm{~mm})$ were added. The tube was sealed, and extraction was accomplished by stirring the mead with $400 \mu \mathrm{L}$ of dichloromethane (Merck, Darmstadt, Germany) for 15 min with a magnetic stirrer. After cooling the solutions at $0{ }^{\circ} \mathrm{C}$ for $10 \mathrm{~min}$, the magnetic stir bar was removed, and the organic phase was separated by centrifugation $\left(R C F=5118 \times \mathrm{g}\right.$ for $5 \mathrm{~min}$ at $\left.4{ }^{\circ} \mathrm{C}\right)$ and transferred into a vial with a Pasteur pipette. Finally, the aromatic extract was dried with anhydrous sodium sulphate (Merck, Darmstadt, Germany) and again transferred into a new vial.

\subsubsection{Chromatographic analysis of minor volatile compounds}

Minor volatile compounds were analysed by GC-MS using a gas chromatograph Varian 3800 with a 1079 injector and an ion-trap mass spectrometer Varian Saturn 2000. A 1- $\mu \mathrm{L}$ injection was made in splitless mode (30 s) in a Varian Factor Four VF-WAXms (30 $\mathrm{m} \times 0.15 \mathrm{~mm} ; 0.15 \mu \mathrm{m}$ film thickness) column. The carrier gas was helium UltraPlus $5 \times(99.9999 \%)$ at a constant flow rate of 


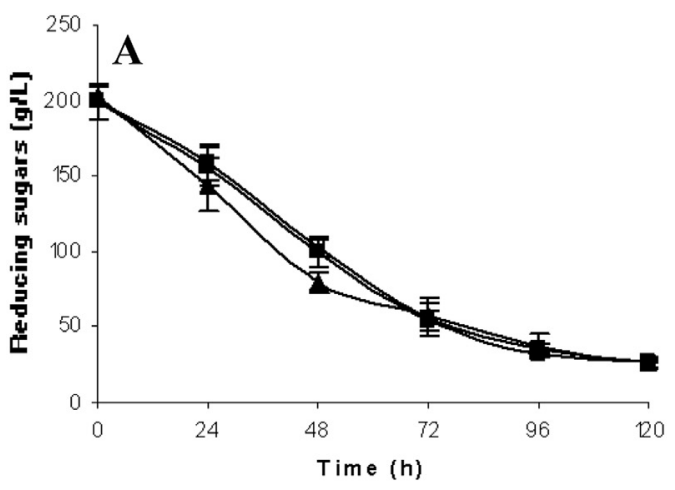

A

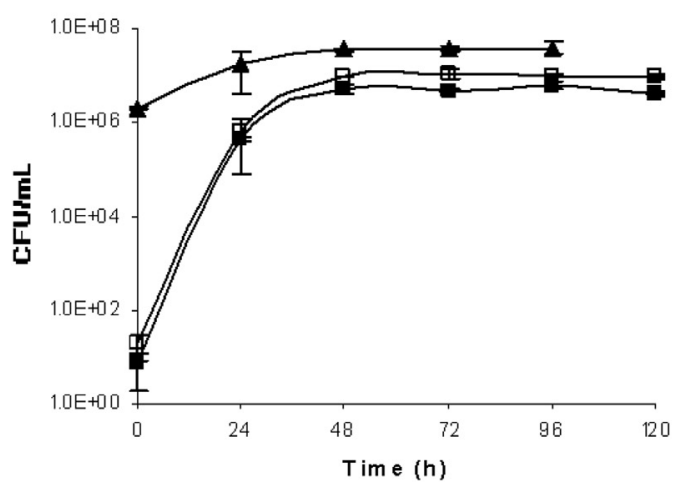

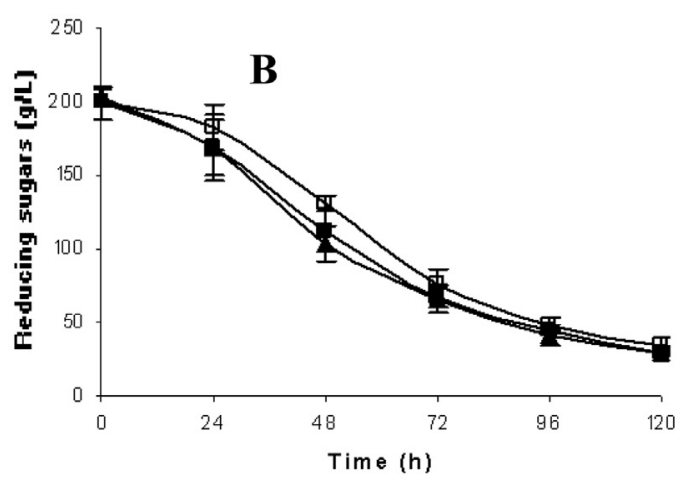

B

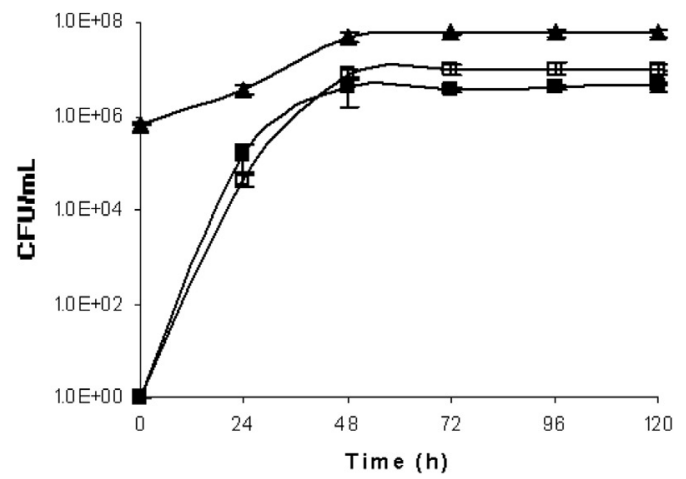

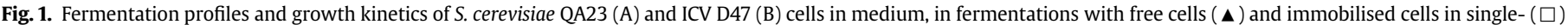
or double-layer ( $\boldsymbol{\square})$ beads.

$1.3 \mathrm{~mL} / \mathrm{min}$. The detector was set to electronic impact mode with an ionisation energy of $70 \mathrm{eV}$, a mass acquisition range from $35 \mathrm{~m} / \mathrm{z}$ to $260 \mathrm{~m} / \mathrm{z}$ and an acquisition interval of $610 \mathrm{~ms}$. The oven temperature was initially $60{ }^{\circ} \mathrm{C}$ for $2 \mathrm{~min}$ and then raised from $60{ }^{\circ} \mathrm{C}$ to $234{ }^{\circ} \mathrm{C}$ at a rate of $3{ }^{\circ} \mathrm{C} / \mathrm{min}$, raised from $234{ }^{\circ} \mathrm{C}$ to $250^{\circ} \mathrm{C}$ at $10^{\circ} \mathrm{C} /$ min and finally maintained at $250^{\circ} \mathrm{C}$ for $10 \mathrm{~min}$. The temperature of the injector was maintained at $250^{\circ} \mathrm{C}$ during the analysis time, and the split flow was maintained at $30 \mathrm{~mL} / \mathrm{min}$. The identification of compounds was performed using MS WorkStation version 6.6 software (Varian) by comparing their mass spectra and retention indices with those of pure standard compounds. The minor compounds were quantified in terms of 4-nonanol equivalents.

\subsubsection{Determination of odour activity values}

The Odour Activity Values (OAVs) were determined to evaluate the contribution of a certain chemical compound to the aroma of mead. Only the compounds with an OAV greater than 1 were considered to give a significant contribution to the mead's aroma (Escudero et al., 2004; Vilanova, Genisheva, Bescansa, Masa, \& Oliveira, 2009). The OAV was calculated for each quantified volatile compound as the ratio between the concentration of an individual compound and the perception threshold found in the literature (Escudero et al., 2004; Ferreira, López, \& Cacho, 2000; Guth, 1997; Moreno, Zea, Moyano, \& Medina, 2005).

\subsection{Statistical analysis}

An analysis of variance (ANOVA) with type III sums of squares was performed using the general linear model procedure as implemented in the SPSS software, version 17.0 (SPSS, Inc.). The fulfilment of the ANOVA requirements, namely the normal distribution of the residuals and the homogeneity of variance, were evaluated by means of the Shapiro-Wilks test $(n<50)$ and Levene's test, respectively. All dependent variables were analysed using a one-way ANOVA. For each strain, the main factor studied was the effect of yeast immobilisation on the physicochemical characteristics and aromatic compounds of meads and if a significant effect was found, the means were compared using Tukey's honestly significant difference multiple comparison test. All statistical tests were performed at a $5 \%$ significance level.

\section{Results and discussion}

Traditional fermentations conducted with free cells were compared with the fermentations using immobilised cells, in single- and double-layer beads. The cell concentrations in both systems were $10^{6} \mathrm{CFUS} / \mathrm{mL}$ of honey-must.

\subsection{Effect of immobilisation on fermentation performance}

Based on previous studies performed by our group, subsequent studies were conducted with $4 \%$ Ca-alginate beads of the two yeast strains (QA23 and ICV D47). To overcome the phenomenon of cell leakage, beside the single-layer immobilisation, immobilised cells in double-layer alginate-chitosan beads were used. Fermentations with free cells were conducted in parallel with immobilised cell fermentations for comparison.

The fermentation kinetics profiles of the free or immobilised cells expressed in terms of sugar consumption are presented in Fig. 1. In all fermentations $50 \%$ of the sugars, or more, were consumed after $48 \mathrm{~h}$ of fermentation, which corresponds to an ethanol concentration of 5-6\% vol. (data not shown). Nevertheless, fermentations conducted with different systems reached the same final ethanol concentration, $10-11 \%$ vol. (Table 2). It has been 
Table 1

Total beads wet weight, CFUs and immobilisation yield of S. cerevisiae QA23 and ICV D47 immobilised cells in single- or double-layer beads.

\begin{tabular}{|c|c|c|c|c|}
\hline & \multicolumn{2}{|l|}{ Strain QA23 } & \multicolumn{2}{|l|}{ Strain ICV D47 } \\
\hline & Single layer immobilisation & Double layer immobilisation & Single layer immobilisation & Double layer immobilisation \\
\hline Total beads wet weight ( $\mathrm{g}$ ) & $10.27 \pm 0.27$ & $10.73 \pm 0.23$ & $11.22 \pm 0.28$ & $11.19 \pm 0.50$ \\
\hline CFUs/mL of alginate & $2.28 \pm 0.08 \times 10^{8}$ & $2.45 \pm 0.98 \times 10^{8}$ & $4.87 \pm 1.51 \times 10^{8}$ & $5.67 \pm 1.95 \times 10^{8}$ \\
\hline Immobilisation yield (\%) & $59.41 \pm 6.30$ & $66.79 \pm 4.21$ & $61.37 \pm 6.69^{\mathrm{a}}$ & $72.89 \pm 2.55^{\mathrm{a}}$ \\
\hline
\end{tabular}

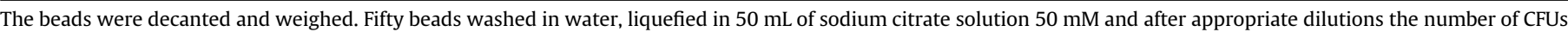

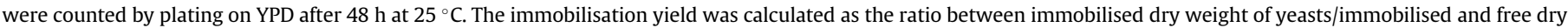
weight of yeasts $\times 100$.

a Significant at $p<0.05$. Lack of a superscript indicates no significant difference, $p>0.05$.

reported higher productivity in the immobilised system than in the free cell system (Nigam, 2000; Yu, Zhang, \& Tan, 2007). However, it is important to state that the fermentation productivity depends on the concentration of yeast cells immobilised in beads (Inal \& Yiğitoğlu, 2011), on the bead-size, as well as on the temperature of fermentation (Diviès \& Cachon, 2005).

Independently of the cell system, the strain ICV D47 presented lower sugar consumption in the first $48 \mathrm{~h}$ than the strain QA23, but fermentations performed with both strains ended $120 \mathrm{~h}$ after inoculation. These results are not in agreement with the findings from other studies, which observed longer fermentation length in free cells on orange peels, when compared with immobilised cells (Plessas et al., 2007). At the end of all fermentations, approximately $30 \mathrm{~g} / \mathrm{L}$ of non-fermentable sugars such as trehalose, isomaltose, saccharose and melezitose (data not shown) remained in all meads, which is in agreement with results previously published by our group (Mendes-Ferreira et al., 2010; Pereira et al., 2013).

For both strains, the reducing sugar consumption profile showed a slight difference between the three cell conditions from the 24 until the $72 \mathrm{~h}$ of fermentation. Nevertheless, minor differences were detected between fermentations conducted with free or encapsulated cells and between the fermentations with cells immobilized in single or double-layer. In fact, Mariam, Manzoor, Ali, and Ikram-ul-Haq (2009) have already mentioned that S. cerevisiae consumed practically the same amount of sugar in free or in immobilised form. Regarding the efficiency of sugar consumption by encapsulated cells, Yu et al. (2007) verified that immobilized ones consumed the sugars faster and more efficiently than the free cells, while Nikolić, Mojović, Rakin, Pejin, and Nedović (2009) found the opposite. The discrepancies might be due to differences in yeast strains, immobilisation agents, must composition and fermentation conditions.

\subsection{Effect of immobilisation on yeast growth}

Colony-forming unit (CFU) in medium analysis indicated an increase in the yeast cell population of both strains QA23 and ICV D47 within the first 24 and $48 \mathrm{~h}$ (Fig. 1). The cell viability remained constant until the end of the experiments, with the number of CFUs slightly higher in fermentation with free cells, which reached almost $10^{8} \mathrm{CFUs} / \mathrm{mL}$. At the beginning of fermentations with singlelayer $\mathrm{Ca}$-alginate and double-layer alginate-chitosan beads no free cells were detected in the fermentation medium. However, 24 or $48 \mathrm{~h}$ after the onset of fermentation, depending on the strain, a considerable increase in cell population was observed, reaching $10^{7} \mathrm{CFUs} / \mathrm{mL}$. That increase in CFUs resulted from the combined effects of the cell leakage from beads, most likely due to the intensive cell growth on peripheral beads section, and to cell proliferation in the medium. Cell leakage was especially prominent during intensive carbon dioxide evolution, most likely due to the creation of pores in the polymer matrix by arising bubbles
(Bezbradica, Obradovic, Leskosek-Cukalovic, Bugarski, \& Nedovic, 2007).

It is important to note that the number of CFUs in fermentations with encapsulated cells was significantly lower than that of control fermentation reflecting the early arrest of yeast cell division most likely because the honey-must lack sufficient nutrients to support both free and encapsulated cells growth. Another explanation for the early arrest of yeast cell division under those conditions might be the space limitation due to the presence of beads. This is in agreement with the fact that no differences were detected in the number of free cells in medium fermented with single-layer Caalginate or double-layer alginate-chitosan beads. Due to cell leakage, it is difficult to determine the contribution of entrapped cells on the fermentation progress. To actually compare traditional fermentations with free cells with the fermentations using encapsulated cells, the cells liberated from the beads have to be periodically withdrawn from the medium.

Cell viability in beads was measured as the power of reproduction after their dissolution in sodium citrate (Table 1 ). In addition, the dry weight of cells in medium and in beads was determined (Fig. 2). For both strains and immobilisation systems the number of CFUs in beads was higher than the number of CFUs of free cells in the outside medium, probably because encapsulated cells are more protected from such harsh environmental conditions. Identical results were obtained for cell dry weight, corroborating identical observations with yeast cells immobilised in PVA particles and on orange peels (Bezbradica et al., 2007; Plessas et al., 2007). In addition, the final overall viable cell concentration in beads plus free cells in medium was higher than the total cell concentration achieved in free cell fermentation, most likely due to the high growth rate of entrapped cells in beads. Nevertheless, the final amounts of viable cells were higher in immobilised systems than in the free system, although the cellular dry weights were lower. This result indicates that the immobilisation has a negligible effect on cell viability, in agreement with previous results obtained with entrapped cells in PVA particles for beer fermentation (Bezbradica et al., 2007). The results also indicated that there was no advantage of using double-layer alginate-chitosan beads, since the final concentration of cells in medium and beads was similar. Nevertheless, an exception was observed in the immobilisation yield of strain ICV D47, which was significant higher in double-layer fermentation.

Cell leakage is considered one of the main problems of the cell immobilisation and was especially prominent during intensive carbon dioxide evolution, most likely due to the creation of pores in the polymer matrix by arising bubbles (Bezbradica et al., 2007). Other reason for this phenomenon is the presence in the fermentation medium of high concentrations of chelating agents, such as $\mathrm{K}^{+}$ions and phosphate, which destroy the formatted gel matrix (Tataridis, Ntagas, Voulgaris, \& Nerantzis, 2005). Cell leakage should be minimised by double-layer immobilisation because the Ca-alginate beads were coated with 
Table 2

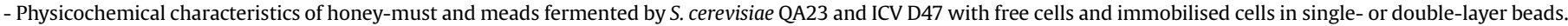
The results are shown as the mean values and their standard deviations.

\begin{tabular}{|c|c|c|c|c|c|c|}
\hline Honey-musts & & & Prior adjustment & & & After adjustment \\
\hline $\mathrm{pH}$ & & & $4.54 \pm 0.05$ & & & $3.71 \pm 0.01$ \\
\hline${ }^{\circ}$ Brix (\%) & & & $22.60 \pm 0.40$ & & & $23.30 \pm 0.20$ \\
\hline Titratable acidity tartaric acid $(\mathrm{g} / \mathrm{L})$ & & & $0.79 \pm 0.17$ & & & $4.94 \pm 0.84$ \\
\hline Initial nitrogen $_{\text {YAN }}(\mathrm{mg} / \mathrm{L})$ & & & $48.30 \pm 5.75$ & & & $273.00 \pm 22.55$ \\
\hline \multirow[t]{2}{*}{ Meads } & \multicolumn{3}{|l|}{ QA 23} & \multicolumn{3}{|l|}{ ICV D47 } \\
\hline & Free system & $\begin{array}{l}\text { Single layer } \\
\text { immobilisation }\end{array}$ & $\begin{array}{l}\text { Double layer } \\
\text { immobilisation }\end{array}$ & Free system & $\begin{array}{l}\text { Single layer } \\
\text { immobilisation }\end{array}$ & $\begin{array}{l}\text { Double layer } \\
\text { immobilisation }\end{array}$ \\
\hline $\mathrm{pH}$ & $3.67 \pm 0.05$ & $3.62 \pm 0.10$ & $3.63 \pm 0.12$ & $3.60 \pm 0.06$ & $3.60 \pm 0.08$ & $3.62 \pm 0.07$ \\
\hline Volatile acidity acetic acid $(\mathrm{g} / \mathrm{L})$ & $0.43 \pm 0.02$ & $0.50 \pm 0.03$ & $0.50 \pm 0.05$ & $0.34 \pm 0.03^{\mathrm{a}}$ & $0.56 \pm 0.03^{b}$ & $0.58 \pm 0.03^{b}$ \\
\hline Titratable acidity tartaric acid $(\mathrm{g} / \mathrm{L})$ & $6.58 \pm 0.27$ & $8.75 \pm 2.31$ & $8.56 \pm 2.15$ & $6.96 \pm 0.15$ & $8.94 \pm 2.23$ & $9.04 \pm 2.34$ \\
\hline Final nitrogen ${ }_{\text {YAN }}(\mathrm{mg} / \mathrm{L})$ & $33.83 \pm 2.02$ & $31.50 \pm 3.50$ & $26.25 \pm 5.25$ & $33.83 \pm 4.04^{\mathrm{b}}$ & $23.33 \pm 4.04^{\mathrm{a}}$ & $31.50 \pm 3.50^{\mathrm{ab}}$ \\
\hline Total $\mathrm{SO}_{2}(\mathrm{mg} / \mathrm{L})$ & $25.60 \pm 2.56$ & $23.89 \pm 3.91$ & $21.76 \pm 1.28$ & $26.03 \pm 3.22$ & $23.47 \pm 3.70$ & $23.04 \pm 2.56$ \\
\hline Ethanol (\% vol) & $11.20 \pm 0.00^{\mathrm{b}}$ & $10.53 \pm 0.12^{\mathrm{a}}$ & $10.81 \pm 0.32 \mathrm{ab}$ & $10.87 \pm 0.12$ & $10.73 \pm 0.32$ & $10.73 \pm 0.20$ \\
\hline
\end{tabular}

${ }^{\mathrm{a}-\mathrm{b}}$ Means within a line with different superscripts differ, $p<0.05$. Lack of a superscript indicates no significant difference, $p>0.05$.

chitosan. Thus, cell leakage is reduced to a significant level with the contribution of both the presence of an outer layer containing no cells coating the single-layer beads and a polyelectrolyte complex of alginate and chitosan (Liouni et al., 2008). Moreover, it is important to take into account in the immobilisation procedure the bead size to minor the phenomenon of cell leakage. Cells entrapped in small diameter beads are generally preferred because provide high solid-liquid interfacial areas per unit reactor volume and minimises mass-transfer limitation problems (Nigam, 2000; Nikolić et al., 2009). In contrast, cells immobilised in a large-size bead proliferate only in the periphery of the bead due to substrate and oxygen limitation (Park \& Chang, 2000). Additionally, $\mathrm{pH}$ is a key factor in avoiding cell leakage because it affects the mechanical stability and integrity of the beads (Vilela, Schuller, Mendes-Faia, \& Côrte-Real, 2013).

\subsection{Effect of immobilisation on mead quality}

The physicochemical characteristics such as $\mathrm{pH}$, volatile acidity, titratable acidity, final assimilable nitrogen, total $\mathrm{SO}_{2}$, ethanol and reducing sugars of meads produced by strain QA23 and ICV D47 with free cells and different immobilisation systems are presented in Table 2. The final $\mathrm{pH}$ of meads was lower than the initial $\mathrm{pH}$ of honey-must but no significant differences were found between cell conditions for both strains. Identical observations were verified for titratable acidity and total $\mathrm{SO}_{2}$. Volatile acidity, expressed as $\mathrm{g} / \mathrm{L}$ of acetic acid, confirms the values of acetic acid obtained by HPLC (Fig. 3) and showed differences between free and immobilised fermentations with strain ICV D47. The ethanol concentration ranged from 10.53 to $11.20 \%$ vol. in meads produced by the strain QA23 with immobilised cells in single-layer Ca-alginate or free cells, respectively. A similar concentration of residual assimilable nitrogen remained in all meads independently of the strain and the condition of cells, most likely corresponding to the concentration of the amino acid proline, which is present in honey but not assimilable by yeasts (Pereira et al., 2013). Concerning the strain ICV D47, the consumption of nitrogen by immobilised cells in single-layer Ca-alginate was significant higher than the consumption by free cells. These results are in accordance with high cell growth in immobilised systems due to the growth of cells inside the beads and in the medium, which can explain the higher consumption of nitrogen in the immobilised system. Others have reported a low consumption of free amino nitrogen linked to a very limited or no cell growth in immobilised yeast systems (Willaert \& Nedovic, 2006).

The concentration of glycerol produced by both strains at the end of fermentations ranged from 5.3 to $6.6 \mathrm{~g} / \mathrm{L}$ (Fig. 3). For both strains, at the end of fermentations, a significant difference was found (results not shown) in glycerol concentration produced by free cells or cells immobilised in double-layer. Higher concentration of glycerol was obtained for the fermentations conducted with free cells. The concentrations of this alcohol determined in all assays were in agreement with the values usually reported in wine (Ribéreau-Gayon, Dubourdieu, Donèche, \& Lonvaud, 2000; Ugliano \& Henschke, 2009) and in meads (Pereira et al., 2009). Environmental factors such as temperature, aeration, nitrogen source,
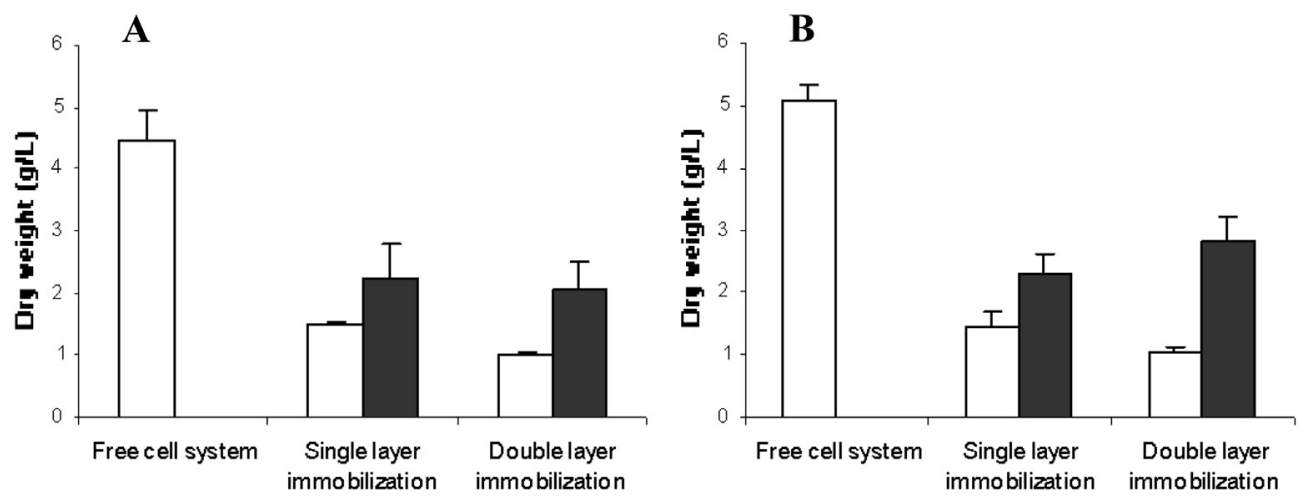

Fig. 2. Dry weight, at the end of fermentation, of S. cerevisiae QA23 (A) and ICV D47 (B) cells suspended in medium ( $\square$ ) and in beads ( immobilised cells in single- or double-layer beads. 

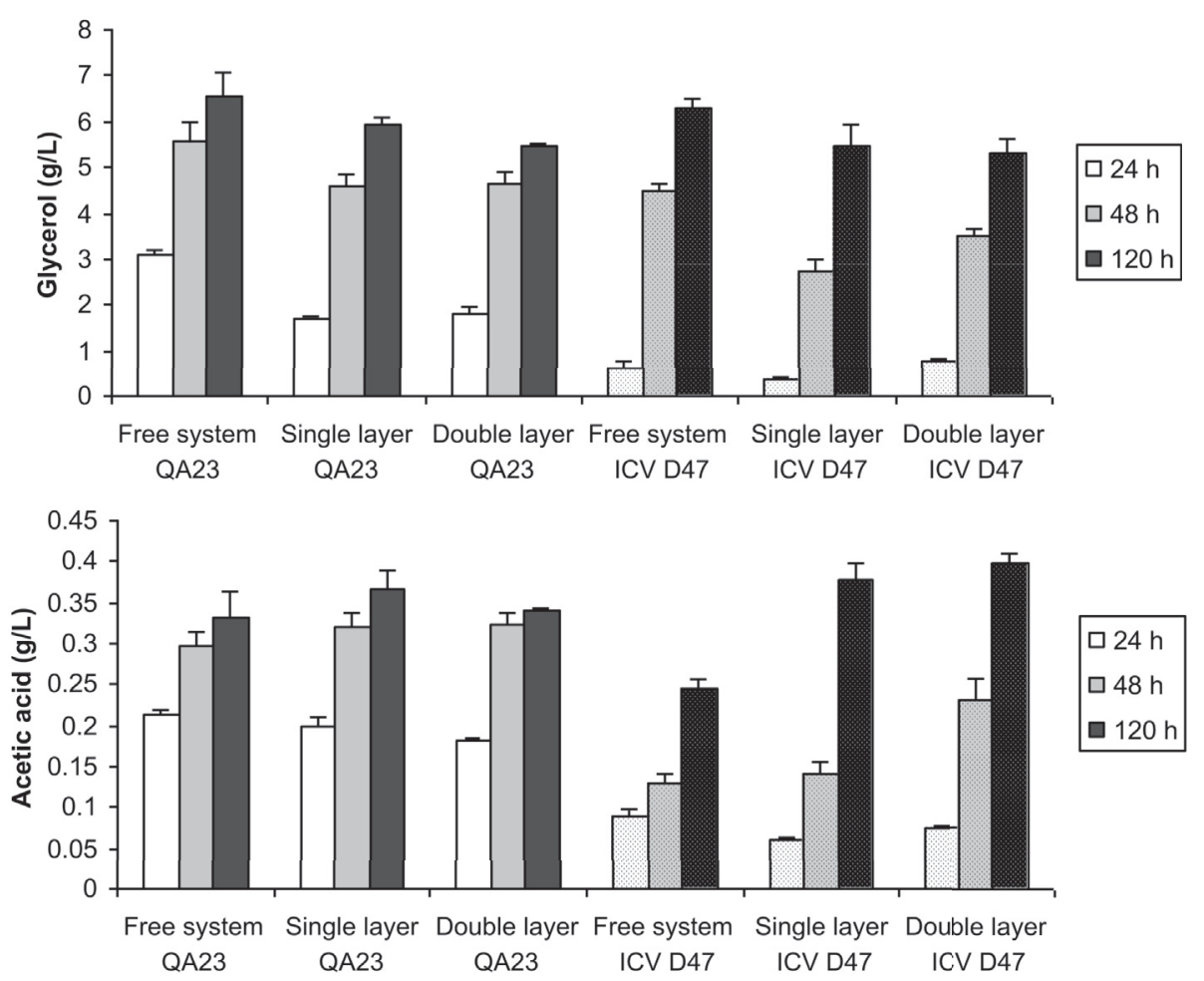

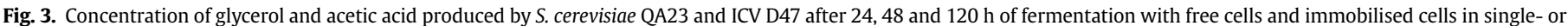
double-layer beads.

sugar concentration and the yeast strain have been found to affect the rate and yield of glycerol production (Remize, Sablayrolles, \& Dequin, 2000). A significant increase in glycerol formation by immobilised cells of $S$. cerevisiae has been reported in the production of alcohol-free beer (van Iersel, Brouwer-Post, Rombouts, \& Abee, 2000), of wine (Balli et al., 2003; Reddy, Reddy, Wee, \& Reddy, 2011) as well as in other fruit-fermented beverage (Oliveira et al., 2011). In contrast, other authors have observed higher amounts of glycerol in fermentations performed with free cells (Genisheva, Macedo, Mussatto, Teixeira, \& Oliveira, 2012; López de Lerma, García-Martínez, Moreno, Mauricio, \& Peinado, 2012). High glycerol production in fermented products using immobilised cells may be a yeast response to the stress conditions imposed by this system (Reddy et al., 2011). Nevertheless, no explanation has been proposed before for the increase in glycerol production by free cells.

In respect to acetic acid production, the immobilisation process had a distinct effect on strain QA23 and ICV D47 (Fig. 3). For strain QA23, the immobilisation did not affect the acetic acid production in mead, where the concentration was approximately $0.3 \mathrm{~g} / \mathrm{L}$ in all meads. Instead, the strain ICV D47 produced almost the double of acetic acid in immobilised than in the free form. Indeed, the difference in acetic acid production between strains or cell conditions has already been reported (Genisheva et al., 2012; van Iersel et al., 2000; López de Lerma et al., 2012; Oliveira et al., 2011). The discrepancies among the results obtained may be explained by differences in yeast strains, medium composition and fermentation conditions. In fact, as previously stated, meads obtained with strain ICV D47 displayed lower volatile acidity than the meads produced by strain QA23, both in the free form (Pereira et al., 2013). Similar concentrations have been observed in mead produced from Portuguese honey (Pereira et al., 2009), whereas Sroka and Tuszyński (2007) reported higher concentrations $(0.75 \mathrm{~g} / \mathrm{L})$.

\subsection{Effect of immobilisation on mead aroma profile}

The alcoholic fermentation produces not only ethanol but also a complex mixture of flavour-active by-products. The concentrations of volatile compounds in meads produced by strain QA23 and ICV D47 immobilised in single-layer Ca-alginate or double-layer alginate-chitosan and in free form are shown in Tables 3 and 4, respectively. A total of twenty-five compounds were identified and quantified, including alcohols, esters, volatile phenols and medium chain fatty acids.

The alcohols were the major group of volatile compounds quantified in all meads. No correlation could be established between the concentration of alcohols and the condition of cells (immobilised or free). The strain QA23 produced less alcohol in meads fermented with single-layer Ca-alginate immobilised cells, whereas the strain ICV D47 produced the lowest concentration of this group of compounds in meads fermented with cells immobilised in double-layer alginate-chitosan (data not shown). However, as desirable for the complexity of alcoholic beverage the concentration of these alcohols should be below $300 \mathrm{mg} / \mathrm{L}$ (Boulton, Singleton, Bisson, \& Kunkee, 1996; Ugliano \& Henschke, 2009). The major alcohol detected in all meads was 3-methyl-1-butanol at a concentration above its perception threshold. In general, the concentration of alcohol compounds decreased or was similar in meads obtained with immobilised cells, with the exception of 1propanol. That alcohol was more produced by immobilised cells over a range of $20.16-31.62 \mathrm{mg} / \mathrm{L}$ for strain QA23 and $24.12-$ $60.12 \mathrm{mg} / \mathrm{L}$ for strain ICV D47. Identical values of 1-propanol to the ones obtained in fermentation with QA23 immobilised in singlelayer Ca-alginate, were observed by Plessas et al. (2007) in anaerobic batch fermentations of glucose by $S$. cerevisiae cells immobilised on orange peels. Normally, the significant lower amounts of 2methyl-1-butanol and 2-phenylethanol were produced by cells immobilised. Higher alcohols individually do not give pleasant 
notes to the beverage, except 2-phenylethanol, but together they can contribute positively to the overall aroma (Genisheva et al., 2012). The concentration of 2-phenylethanol in all meads was above their perception threshold, $14 \mathrm{mg} / \mathrm{L}$ (Escudero et al., 2004; Guth, 1997), and similar concentrations have already been reported in wines fermented with free or immobilised cells of S. cerevisiae (Genisheva et al., 2012).

The second major group of compounds quantified in meads was the esters, which give fruity/flowery nuances to the aroma of fermented beverages (Swiegers, Bartowsky, Henschke, \& Pretorius, 2005; Willaert \& Nedovic, 2006). Meads obtained with immobilised cells presented higher concentrations of esters, but no remarkable differences were detected between the two strains, as reported in literature (Willaert \& Nedovic, 2006). The major ester in all meads was ethyl acetate, with a concentration ranging from 35.41 to $53.46 \mathrm{mg} / \mathrm{L}$, in accordance to previous results on mead fermentation (Mendes-Ferreira et al., 2010). Larger amounts of ethyl acetate were produced by cells immobilised in double-layer alginate-chitosan, and the strain IVC D47 produced significant less ethyl acetate, when free cell systems were applied. These results are in accordance to Genisheva et al. (2012) and Reddy et al. (2011) who observed higher concentrations of ethyl acetate in fermentations using immobilised cells, whereas Tsakiris et al. (2004) observed higher concentrations in fermentations using free cells. The strain QA23 produced ethyl octanoate and ethyl

Table 3

- Concentration of volatile compounds of meads fermented S. cerevisiae QA23 with free cells and immobilised cells in single- or double-layer beads. The results are shown as the mean values and their standard deviations.

\begin{tabular}{|c|c|c|c|}
\hline & Free cell system & $\begin{array}{l}\text { Single-layer } \\
\text { immob. }\end{array}$ & $\begin{array}{l}\text { Double-layer } \\
\text { immob. }\end{array}$ \\
\hline \multicolumn{4}{|l|}{ Alcohols (mg/L) } \\
\hline 1-Propanol & $20.16 \pm 1.05^{\mathrm{a}}$ & $25.45 \pm 6.02^{\mathrm{ab}}$ & $31.62 \pm 3.47^{\mathrm{b}}$ \\
\hline $\begin{array}{c}\text { 2-Methyl-1- } \\
\text { propanol }\end{array}$ & $23.98 \pm 2.29^{b}$ & $17.33 \pm 1.97^{\mathrm{a}}$ & $20.76 \pm 1.56$ \\
\hline $\begin{array}{l}\text { 2-Methyl-1- } \\
\text { butanol }\end{array}$ & $18.80 \pm 2.73^{b}$ & $13.28 \pm 1.70^{\mathrm{a}}$ & $16.09 \pm 1.74^{\mathrm{ab}}$ \\
\hline $\begin{array}{l}\text { 3-Methyl-1- } \\
\text { butanol }\end{array}$ & $141.86 \pm 18.93$ & $120.59 \pm 19.48$ & $143.49 \pm 16.54$ \\
\hline 2-Phenylethanol & $29.09 \pm 3.43^{b}$ & $21.06 \pm 1.91^{\mathrm{a}}$ & $27.52 \pm 1.93^{b}$ \\
\hline $\begin{array}{l}\text { 3-Ethoxy-1- } \\
\text { propanol }\end{array}$ & $0.13 \pm 0.04$ & $0.16 \pm 0.08$ & $0.16 \pm 0.05$ \\
\hline $\begin{array}{l}\text { 3-(Methylthio)- } \\
\text { 1-propanol }\end{array}$ & $0.07 \pm 0.02^{b}$ & $0.04 \pm 0.01^{\mathrm{ab}}$ & $0.04 \pm 0.004^{\mathrm{a}}$ \\
\hline \multicolumn{4}{|l|}{ Esters (mg/L) } \\
\hline Ethyl acetate & $35.66 \pm 3.15$ & $44.54 \pm 10.10$ & $53.46 \pm 10.42$ \\
\hline Ethyl butyrate & $0.10 \pm 0.01$ & $0.12 \pm 0.03$ & $0.12 \pm 0.01$ \\
\hline Isoamyl acetate & $1.15 \pm 0.05$ & $1.28 \pm 0.38$ & $1.27 \pm 0.20$ \\
\hline Ethyl hexanoate & $0.21 \pm 0.02$ & $0.25 \pm 0.05$ & $0.27 \pm 0.03$ \\
\hline Ethyl lactate & $0.03 \pm 0.01$ & $0.03 \pm 0.01$ & $0.03 \pm 0.01$ \\
\hline Ethyl octanoate & $0.14 \pm 0.04^{\mathrm{a}}$ & $0.23 \pm 0.03^{\mathrm{ab}}$ & $0.25 \pm 0.06^{\mathrm{b}}$ \\
\hline Ethyl decanoate & $0.06 \pm 0.03^{\mathrm{a}}$ & $0.12 \pm 0.02^{a b}$ & $0.17 \pm 0.05^{b}$ \\
\hline $\begin{array}{l}\text { Ethyl } \\
\text { phenylacetate }\end{array}$ & $0.002 \pm 0.001$ & $0.002 \pm 0.000$ & $0.002 \pm 0.001$ \\
\hline $\begin{array}{l}\text { 2-Phenylethyl } \\
\text { acetate }\end{array}$ & $0.46 \pm 0.12$ & $0.52 \pm 0.14$ & $0.41 \pm 0.05$ \\
\hline \multicolumn{4}{|c|}{ Volatile phenols $(\mu \mathrm{g} / \mathrm{L})$} \\
\hline 4-Vinylguaiacol & $79.17 \pm 17.90$ & $75.99 \pm 14.40$ & $80.23 \pm 7.53$ \\
\hline 4-Vinylphenol & $115.06 \pm 21.10$ & $111.53 \pm 26.53$ & $112.86 \pm 14.88$ \\
\hline \multicolumn{4}{|c|}{ Medium chain fatty acids $(\mu \mathrm{g} / \mathrm{L})$} \\
\hline Isobutyric acid & $25.59 \pm 5.54^{\mathrm{b}}$ & $12.34 \pm 4.24^{\mathrm{a}}$ & $10.68 \pm 1.90^{\mathrm{a}}$ \\
\hline Butanoic acid & $10.96 \pm 3.82$ & $10.00 \pm 4.04$ & $8.69 \pm 2.05$ \\
\hline Hexanoic acid & $510.42 \pm 141.89$ & $557.86 \pm 158.16$ & $527.63 \pm 81.50$ \\
\hline Octanoic acid & $1533.17 \pm 287.61$ & $1880.71 \pm 456.45$ & $1934.90 \pm 175.73$ \\
\hline Decanoic acid & $268.94 \pm 60.59$ & $358.03 \pm 149.45$ & $469.90 \pm 30.82$ \\
\hline Dodecanoic acid & $5.10 \pm 4.08$ & $3.31 \pm 1.18$ & $1.84 \pm 0.82$ \\
\hline \multicolumn{4}{|c|}{ Carbonyl compounds (mg/L) } \\
\hline Acetaldehyde & $7.45 \pm 1.60$ & $5.02 \pm 0.46$ & $8.27 \pm 3.38$ \\
\hline
\end{tabular}

a-b Means within a line with different superscripts differ, $p<0.05$. Lack of a superscript indicates no significant difference, $p>0.05$. decanoate in significant higher amounts immobilised in doublelayer alginate-chitosan than in the free form. Different results were obtained in fermentation with the strain ICV D47, which produced more 2-phenylethyl acetate using free cells and oppositely produced more ethyl hexanoate in fermentations using single- or double-layer cells. In contrast, Genisheva et al. (2012) found higher amounts of both esters in fermentations using immobilised cells.

The volatile phenols, 4-vinylphenol and 4-vinylguaiacol, considered as off-flavours because they give an unpleasant aroma of wet animal (Swiegers et al., 2005), were quantified herein at concentrations below their perception threshold. However, no significant differences were detected between the strains or cells conditions.

Six medium-chain fatty acids (MCFA) were identified and quantified in all meads. Octanoic acid was the major MCFA quantified in all meads, and it was observed in concentrations above its perception threshold $(0.5 \mathrm{mg} / \mathrm{L})$. The concentration of this compound was highly variable in fermentations using free or immobilised cells in double-layer of the strain ICV D47, whereas no differences were detected in fermentations conducted with the strain QA23. High concentrations of octanoic and decanoic acids have been reported in wines obtained with immobilised cells on grape pomace peels (Genisheva et al., 2012). Isobutyric acid was the only MCFA that displayed significant differences in its

\section{Table 4}

Concentration of volatile compounds of meads fermented $S$. cerevisiae ICV D47 with free cells and immobilised cells in single- or double-layer beads. The results are shown as the mean values and their standard deviations.

\begin{tabular}{|c|c|c|c|}
\hline & Free cell system & $\begin{array}{l}\text { Single-layer } \\
\text { immob. }\end{array}$ & $\begin{array}{l}\text { Double-layer } \\
\text { immob. }\end{array}$ \\
\hline \multicolumn{4}{|l|}{ Alcohols (mg/L) } \\
\hline 1-Propanol & $24.12 \pm 1.32^{\mathrm{a}}$ & $60.12 \pm 3.20^{\mathrm{b}}$ & $57.97 \pm 10.64^{\mathrm{b}}$ \\
\hline $\begin{array}{c}\text { 2-Methyl-1- } \\
\text { propanol }\end{array}$ & $20.88 \pm 1.30$ & $22.04 \pm 1.02$ & $19.91 \pm 0.33$ \\
\hline $\begin{array}{l}\text { 2-Methyl-1- } \\
\text { butanol }\end{array}$ & $22.15 \pm 1.50^{\mathrm{b}}$ & $18.27 \pm 1.66^{\mathrm{a}}$ & $15.19 \pm 1.02^{\mathrm{a}}$ \\
\hline $\begin{array}{l}\text { 3-Methyl-1- } \\
\text { butanol }\end{array}$ & $157.26 \pm 6.87^{b}$ & $141.20 \pm 13.98^{a b}$ & $120.03 \pm 6.45^{a}$ \\
\hline 2-Phenylethanol & $33.68 \pm 2.35^{\mathrm{b}}$ & $33.89 \pm 4.89^{\mathrm{b}}$ & $17.96 \pm 1.10^{\mathrm{a}}$ \\
\hline $\begin{array}{c}\text { 3-Ethoxy-1- } \\
\text { propanol }\end{array}$ & $0.01 \pm 0.003$ & $0.01 \pm 0.003$ & $0.01 \pm 0.001$ \\
\hline $\begin{array}{l}\text { 3-(Methylthio)- } \\
\text { 1-propanol }\end{array}$ & $0.08 \pm 0.01^{\mathrm{b}}$ & $0.02 \pm 0.005^{\mathrm{a}}$ & $0.02 \pm 0.01^{\mathrm{a}}$ \\
\hline \multicolumn{4}{|l|}{ Esters $(\mathrm{mg} / \mathrm{L})$} \\
\hline Ethyl acetate & $35.41 \pm 4.15^{\mathrm{a}}$ & $49.92 \pm 1.11^{b}$ & $50.75 \pm 1.50^{\mathrm{b}}$ \\
\hline Ethyl butyrate & $0.09 \pm 0.01^{\mathrm{a}}$ & $0.11 \pm 0.01 \mathrm{ab}$ & $0.12 \pm 0.01^{\mathrm{b}}$ \\
\hline Isoamyl acetate & $1.61 \pm 0.28^{\mathrm{b}}$ & $1.06 \pm 0.05^{\mathrm{a}}$ & $1.16 \pm 0.12^{\mathrm{ab}}$ \\
\hline Ethyl hexanoate & $0.18 \pm 0.01^{\mathrm{a}}$ & $0.26 \pm 0.02^{\mathrm{b}}$ & $0.27 \pm 0.04^{\mathrm{b}}$ \\
\hline Ethyl lactate & $0.03 \pm 0.004$ & $0.03 \pm 0.01$ & $0.03 \pm 0.003$ \\
\hline Ethyl octanoate & $0.10 \pm 0.01$ & $0.16 \pm 0.04$ & $0.17 \pm 0.03$ \\
\hline Ethyl decanoate & $0.04 \pm 0.01$ & $0.06 \pm 0.02$ & $0.05 \pm 0.005$ \\
\hline $\begin{array}{l}\text { Ethyl } \\
\text { phenylacetate }\end{array}$ & $0.002 \pm 0.000$ & $0.001 \pm 0.000$ & $0.002 \pm 0.000$ \\
\hline $\begin{array}{l}\text { 2-Phenylethyl } \\
\text { acetate }\end{array}$ & $0.70 \pm 0.05^{\mathrm{b}}$ & $0.28 \pm 0.02^{\mathrm{a}}$ & $0.24 \pm 0.04^{\mathrm{a}}$ \\
\hline \multicolumn{4}{|c|}{ Volatile phenols $(\mu \mathrm{g} / \mathrm{L})$} \\
\hline 4-Vinylguaiacol & $91.55 \pm 12.24$ & $82.82 \pm 4.34$ & $83.85 \pm 20.06$ \\
\hline 4-Vinylphenol & $118.78 \pm 21.53$ & $104.73 \pm 7.25$ & $102.72 \pm 27.13$ \\
\hline \multicolumn{4}{|c|}{ Medium chain fatty acids $(\mu \mathrm{g} / \mathrm{L})$} \\
\hline Isobutyric acid & $23.02 \pm 5.95^{\mathrm{b}}$ & $11.11 \pm 2.71^{\mathrm{a}}$ & $10.53 \pm 2.88^{\mathrm{a}}$ \\
\hline Butanoic acid & $8.67 \pm 3.61$ & $9.77 \pm 3.29$ & $10.23 \pm 2.68$ \\
\hline Hexanoic acid & $426.20 \pm 90.90$ & $508.39 \pm 95.45$ & $504.31 \pm 78.59$ \\
\hline Octanoic acid & $1439.98 \pm 71.23^{\mathrm{a}}$ & $1557.63 \pm 166.10^{\mathrm{ab}}$ & $1799.55 \pm 153.28^{\mathrm{b}}$ \\
\hline Decanoic acid & $224.37 \pm 24.09$ & $205.02 \pm 45.85$ & $294.28 \pm 35.27$ \\
\hline Dodecanoic acid & $2.10 \pm 0.81$ & $1.84 \pm 0.83$ & $1.05 \pm 0.43$ \\
\hline \multicolumn{4}{|c|}{ Carbonyl compounds (mg/L) } \\
\hline Acetaldehyde & $5.87 \pm 0.33$ & $11.43 \pm 4.68$ & $6.14 \pm 1.26$ \\
\hline
\end{tabular}


Table 5

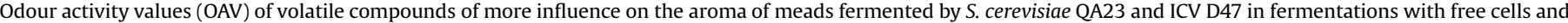
immobilised cells in single- or double-layer beads.

\begin{tabular}{|c|c|c|c|c|c|c|c|c|}
\hline \multirow[t]{2}{*}{ Compounds } & \multirow[t]{2}{*}{ Odour descriptor $^{\mathrm{a}}$} & \multirow{2}{*}{$\begin{array}{l}\text { Odour threshold } \\
(\mu \mathrm{g} / \mathrm{L})^{\mathrm{a}}\end{array}$} & \multicolumn{3}{|l|}{ QA23 } & \multicolumn{3}{|l|}{ ICV D47 } \\
\hline & & & $\begin{array}{l}\text { Free cell } \\
\text { system }\end{array}$ & $\begin{array}{l}\text { Single layer } \\
\text { immobilisation }\end{array}$ & $\begin{array}{l}\text { Double layer } \\
\text { immobilisation }\end{array}$ & $\begin{array}{l}\text { Free cell } \\
\text { system }\end{array}$ & $\begin{array}{l}\text { Single } \\
\text { layer } \\
\text { immobilisation }\end{array}$ & $\begin{array}{l}\text { Double layer } \\
\text { immobilisation }\end{array}$ \\
\hline 3-Methyl-1-butanol & $\begin{array}{l}\text { Cheese; } \\
\text { nail polish }\end{array}$ & 30000 & 4.7 & 4.0 & 4.8 & 5.2 & 4.7 & 4.0 \\
\hline 2-Phenylethanol & Roses; flowery & 14000 & 2.1 & 1.5 & 2.0 & 2.4 & 2.4 & 1.3 \\
\hline Ethyl butyrate & Fruity; sweet & 20 & 5.0 & 5.8 & 5.9 & 4.5 & 5.7 & 6.0 \\
\hline Ethyl hexanoate & Fruity; aniseed & 14 & 15.2 & 18.1 & 19.6 & 13.1 & 18.4 & 19.5 \\
\hline Ethyl octanoate & Fruity; sweet & 5 & 27.8 & 46.4 & 50.6 & 19.7 & 32.3 & 33.5 \\
\hline Ethyl acetate & $\begin{array}{l}\text { Solvent; } \\
\text { nail polish }\end{array}$ & 12300 & 2.9 & 3.6 & 4.3 & 2.9 & 4.1 & 4.1 \\
\hline Isoamyl acetate & Banana & 30 & 38.2 & 42.8 & 42.3 & 53.6 & 35.4 & 38.5 \\
\hline $\begin{array}{l}\text { 2-Phenylethyl } \\
\text { acetate }\end{array}$ & Flowery; roses & 250 & 1.9 & 2.1 & 1.6 & 2.8 & 1.1 & 1.0 \\
\hline Hexanoic acid & Cheese; sweaty & 420 & 1.2 & 1.3 & 1.3 & 1.0 & 1.2 & 1.2 \\
\hline Octanoic acid & Fatty; rancid & 500 & 3.1 & 3.8 & 3.9 & 2.9 & 3.1 & 3.6 \\
\hline Acetaldehyde & Fresh; green leaves & 500 & 14.9 & 10.0 & 16.5 & 11.7 & 22.9 & 12.3 \\
\hline
\end{tabular}

${ }^{a}$ Odour descriptors and odour threshold reported in the literature (Escudero et al, 2004; Ferreira et al, 2000; Guth, 1997; Moreno et al, 2005).

concentrations for both strains, depending on the system used (free or immobilised).

The concentration of acetaldehyde ranged from 5.02 to $11.43 \mathrm{mg} / \mathrm{L}$, always above its perception threshold $(0.5 \mathrm{mg} / \mathrm{L})$, and no differences were found between cells conditions for both strains. Tsakiris et al. (2004) reported high amounts of acetaldehyde in fermentations with free cells compared to fermentations using cells immobilised on dried raisin berries.

In summary, the major differences between our findings and other studies result from the use of different strains, different fermentation conditions and media composition. In fact, the differences in mead flavour are most likely determined by amino acid metabolism and thus the growth of the yeast cells (Verbelen et al., 2006).

To evaluate the contribution of the volatile compounds to the aroma of mead, the odour activity values (OAVs) were determined. However, individual OAVs can serve as estimates for the potential contribution of each compound to the global aroma, but do not account for the antagonistic or synergistic effects resulting from the perceptual interactions between different molecules present in wines (Vilanova et al., 2009). The OAVs of volatile compounds with more influence on mead aroma profile are presented in Table 5. Only eleven volatile compounds out of the twenty-five quantified most likely have a more significant contribution to mead's aroma. The most aromatic meads were produced by strain QA23 immobilised in double-layer alginatechitosan. In general, the meads produced by strain ICV D47 were less aromatic than the ones obtained with strain QA23 in agreement with previous results obtained with the same strains but with different inocula size (Pereira et al., 2013). The most aromatic mead produced by strain ICV D47 was the one fermented with cells immobilised in single-layer $\mathrm{Ca}$-alginate. Indeed, the less aromatic meads were the ones obtained with free cells, irrespective the yeast strain used. However, the OAVs of the undesirable compounds, such as ethyl acetate, octanoic acid and hexanoic acid, were higher in fermentations using immobilised cells. The most powerful odorants in meads were ethyl octanoate, isoamyl acetate and ethyl hexanoate, as already reported in literature (Pereira et al., 2013). All these esters, contribute with desirable characteristics, such as floral/fruity notes for mead aroma profile (Guth, 1997; Moreno et al., 2005). Interestingly, the OAVs of these three compounds were higher in fermentations using immobilised cells.

\section{Conclusions}

The present study aimed to evaluate the effect of using immobilised cell systems on mead production. Our results demonstrate that the immobilisation of yeasts in $\mathrm{Ca}$-alginate did not negatively affect the fermentation process. Minor differences were detected in the fermentation length and in the rate between fermentations conducted with free or immobilised cells, even though higher concentrations of viable cells were achieved in immobilised systems. The phenomenon of cell leakage, one of the major problems encountered in cell immobilisation was not reduced by the use of double-layer alginate-chitosan, and was probably responsible for the main differences observed between free and immobilised fermentations.

Although the most aromatic meads were the ones produced by immobilised cells, the OAVs of undesirable compounds were also higher in these fermentations. It appears that immobilisation has minor advantages for mead production. Despite this, the scale-up of the process can be studied because of unrealised cost advantages, several engineering problems and altered yeast physiological and metabolic properties, which may influence the flavour of the beverage or the fermentation performance. Sensorial analysis of meads could complement the analysis of aroma compounds and therefore allow inferring about its acceptance by consumers.

\section{Acknowledgements}

The research presented in this paper was partially funded by the Fundação para a Ciência e Tecnologia, (FCT) and by PTDC projects (contracts PTDC/AGR-ALI/68284/2006). A.P.P. is a recipient of a Ph.D. grant from the FCT (SFRH/BD/45820/2008).

\section{References}

Aerny, J. (1996). Composés azotes des moûts et des vins. Revue Suisse de Viticulture, Arboriculture, Horticulture, 28, 161-165.

Balli, D., Flari, V., Sakellaraki, E., Schoina, V., Iconomopoulou, M., Bekatorou, A., et al. (2003). Effect of yeast cell immobilization and temperature on glycerol content in alcoholic fermentation with respect to wine making. Process Biochemistry, 39, 499-506.

Bezbradica, D., Obradovic, B., Leskosek-Cukalovic, I., Bugarski, B., \& Nedovic, V. (2007). Immobilization of yeast cells in PVA particles for beer fermentation. Process Biochemistry., 42, 1348-1351.

Boulton, B., Singleton, V. L., Bisson, L. F., \& Kunkee, R. E. (1996). Principles and practices of winemaking. New York: Chapman and Hall. 
Diviès, C., \& Cachon, R. (2005). Wine production by immobilised cell systems. In V. Nedović, \& R. Willaert (Eds.), Applications of cell immobilisation biotechnology (pp. 285-293). Netherlands: Springer.

Escudero, A., Gogorza, B., Melús, M. A., Ortín, N., Cacho, J., \& Ferreira, V. (2004). Characterization of the aroma of a wine from Maccabeo. Key role played by compounds with low odor activity values. Journal of Agricultural and Food Chemistry., 52(11), 3516-3524.

Ferreira, V., López, R., \& Cacho, J. F. (2000). Quantitative determination of the odorants of young red wines from different grape varieties. Journal of Science and Food Agriculture, 80, 1659-1667.

Genisheva, Z., Macedo, S., Mussatto, S. I., Teixeira, J. A., \& Oliveira, J. M. (2012). Production of white wine by Saccharomyces cerevisiae immobilized on grape pomace. Journal of the Institute of Brewing, 118, 163-173.

Göksungur, Y., \& Zorlu, N. (2001). Production of ethanol from beet molasses by Caalginate immobilized yeast cells in a packed-bed bioreactor. Turkish Journal of Biology, 25, 265-275.

Guth, H. (1997). Quantification and sensory studies of character impact odorants of different white wine varieties. Journal of Agricultural and Food Chemistry, 45(8), 3027-3032.

van Iersel, M. F. M., Brouwer-Post, E., Rombouts, F. M., \& Abee, T. (2000). Influence of yeast immobilization on fermentation and aldehyde reduction during the production of alcohol-free beer. Enzyme and Microbial Technology, 26, 602-607.

Inal, M., \& Yiğitoğlu, M. (2011). Production of bioethanol by immobilized Saccharomyces cerevisiae onto modified sodium alginate gel. Journal of Chemical Technology \& Biotechnology, 86, 1548-1554.

Kocher, G. S., Kalra, K. L., \& Phutela, R. P. (2006). Comparative production of sugarcane vinegar by different immobilization techniques. Journal of the Institute of Brewing, 112(3), 264-266.

Koguchi, M., Saigusa, N., \& Teramoto, Y. (2009). Production and antioxidative activity of mead made from honey and black rice (Oryza sativa var. Indica cv. Shiun). Journal of the Institute of Brewing, 115(3), 238-242.

Kostov, G., Angelov, M., Mihaylov, I., \& Poncelet, D. (2010). Mechanical properties of Ca-alginate beads for ethanol fermentation with immobilized yeast. Revue de Génie Industriel, 5, 25-35.

Kourkoutas, Y., Bekatorou, A., Banat, I. M., Marchant, R., \& Koutinas, A. A. (2004). Immobilization technologies and support materials suitable in alcohol beverages production: a review. Food Microbiology, 21, 377-397.

Liouni, M., Drichoutis, P., \& Nerantzis, E. T. (2008). Studies of the mechanical properties and the fermentation behaviour of double layer alginate-chitosan beads, using Saccharomyces cerevisiae entrapped cells. World Journal of Microbiology and Biotechnology, 24, 281-288.

López de Lerma, N., García-Martínez, T., Moreno, J., Mauricio, J. C., \& Peinado, R. A. (2012). Volatile composition of partially fermented wines elaborated from sun dried Pedro Ximénez grapes. Food Chemistry, 135, 2445-2452.

Mariam, I., Manzoor, K., Ali, S., \& Ikram-ul-Haq. (2009). Enhanced production of ethanol from free and immobilized Saccharomyces cerevisiae under stationary culture. Pakistan Journal of Botany, 41(2), 821-833.

Maugenet, J. (1964). L'Hydromel. Annales de l'Abeille, 7, 165-179.

Mendes-Ferreira, A., Barbosa, C., Falco, V., Leão, C., \& Mendes-Faia, A. (2009). The production of hydrogen sulphide and other aroma compounds by wine strains of Saccharomyces cerevisiae in synthetic media with different nitrogen concentrations. Journal of Industrial Microbiology and Biotechnology, 36, 571-583.

Mendes-Ferreira, A., Cosme, F., Barbosa, C., Falco, V., Inês, A., \& Mendes-Faia, A. (2010). Optimization of honey-must preparation and alcoholic fermentation by Saccharomyces cerevisiae for mead production. International Journal of Food Microbiology, 144, 193-198.

Moreno, J. A., Zea, L., Moyano, L., \& Medina, M. (2005). Aroma compounds as markers of the changes in sherry wines subjected to biological ageing. Food Control, 16, 333-338.

Navrátil, M., Šturdík, E., \& Gemeiner, P. (2001). Batch and continuous mead production with pectate immobilised, ethanol-tolerant yeast. Biotechnology Letters, 23, 977-982.

Nigam, J. N. (2000). Continuous ethanol production from pineapple cannery waste using immobilized yeast cells. Journal of Biotechnology, 80, 189-193.

Nikolić, S., Mojović, L., Rakin, M., Pejin, D., \& Nedović, V. (2009). Effect of different fermentation parameters on bioethanol production from corn meal hydrolyzates by free and immobilized cells of Saccharomyces cerevisiae var. ellipsoideus. Journal of Chemical Technology E' Biotechnology, 84, 497-503.

Oliveira, J. M., Faria, M., Sá, F., Barros, F., \& Araújo, I. M. (2006). C6-alcohols as varietal markers for assessment of wine origin. Analytica Chimica Acta, 563, 300-309.

Oliveira, M. E. S., Pantoja, L., Duarte, W. F., Collela, C. F., Valarelli, L. T., Schwan, R. F., et al. (2011). Fruit wine produced from cagaita (Eugenia dysenterica DC) by both free and immobilised yeast cell fermentation. Food Research International, 44, 2391-2400.
Organisation International de la Vigne e du Vin. (2006). Recueil des méthodes internationales d'analyse des vins et des mouts. Paris: OIV.

Pajic-Lijakovic, I., Plavsic, M., Nedovic, V., \& Bugarski, B. (2010). Ca-alginate hydroge rheological changes caused by yeast cell growth dynamics. In A. Méndez-Vilas (Ed.), Current research, technology and education topics in applied microbiology and microbial biotechnology: Vol. 2 (2). Microbiology book series (pp. 1486-1493). Badajoz: Formatex Research Center.

Park, J. K., \& Chang, H. N. (2000). Microencapsulation of microbial cells. Biotech nology Advances, 18, 303-319.

Pereira, A. P., Dias, T., Andrade, J., Ramalhosa, E., \& Estevinho, L. M. (2009). Mead production: selection and characterization assays of Saccharomyces cerevisiae strains. Food and Chemical Toxicology, 47, 2057-2063.

Pereira, A. P., Mendes-Ferreira, A., Oliveira, J. M., Estevinho, L. M., \& Mendes-Faia, A. (2013). High-cell-density fermentation of Saccharomyces cerevisiae for the optimisation of mead production. Food Microbiology, 33, 114-123.

Pilkington, P. H., Margaritis, A., Mensour, N. A., \& Russel, I. (1998). Fundamentals of immobilised yeast cells for continuous beer fermentation: a review. Journal of the Institute of Brewing, 104, 19-31.

Plessas, S., Bekatorou, A., Koutinas, A. A., Soupioni, M., Banat, I. M., \& Marchant, R. (2007). Use of Saccharomyces cerevisiae cells immobilized on orange peel as biocatalyst for alcoholic fermentation. Bioresource Technology, 98, 860-865.

Qureshi, N., \& Tamhane, D. V. (1986). Mead production by continuous series reactors using immobilized yeast cells. Applied Microbiology and Biotechnology, 23, 438-439.

Ramalhosa, E., Gomes, T., Pereira, A. P., Dias, T., \& Estevinho, L. M. (2011). Mead production: tradition versus modernity. In R. S. Jackson (Ed.), Advances in food and nutrition research (pp. 101-118). Burlington: Academic Press.

Reddy, L. V., Reddy, Y. H. K., Reddy, L. P. A., \& Reddy, O. V. S. (2008). Wine production by novel yeast biocatalyst prepared by immobilization on watermelon (Citrullus vulgaris) rind pieces and characterization of volatile compounds. Process Biochemestry, 43, 748-752.

Reddy, L. V., Reddy, L. P., Wee, Y. J., \& Reddy, O. V. S. (2011). Production and characterization of wine with sugarcane piece immobilized yeast biocatalyst. Food Bioprocess Technology, 4, 142-148.

Remize, F., Sablayrolles, J. M., \& Dequin, S. (2000). Re-assessment of the influence of yeast strain and environmental factors on glycerol production in wine. Journal of Applied Microbiology, 88, 371-378.

Ribéreau-Gayon, P., Dubourdieu, D., Donèche, B., \& Lonvaud, A. (2000). Handbook of enology. In The microbiology of wine and vinifications (Vol. 1). Chichester: John Wiley \& Sons Ltd.

Sroka, P. \& Tuszyński, T. (2007). Changes in organic acid contents during mead wort fermentation. Food Chemistry, 104, 1250-1257.

Swiegers, J. H., Bartowsky, E. J., Henschke, P. A., \& Pretorius, I. S. (2005). Yeast and bacterial modulation of wine aroma and flavour. Australian Journal of Grape and Wine Research, 11, 139-173.

Tataridis, P., Ntagas, P., Voulgaris, I., \& Nerantzis, E. T. (2005). Production of sparkling wine with immobilized yeast fermentation. Electronic Journal of Science $\mathcal{E}$ Technology, 1, 1-21.

Teramoto, Y., Sato, R., \& Ueda, S. (2005). Characteristics of fermentation yeast isolated from traditional Ethiopian honey wine, ogol. African Journal of Biotechnology, 4, 160-163.

Tsakiris, A., Bekatorou, A., Psarianos, C., Koutinas, A. A., Marchant, R., \& Banat, I. M. (2004). Immobilization of yeast on dried raisin berries for use in dry white wine-making. Food Chemistry, 87, 11-15.

Ugliano, M., \& Henschke, P. A. (2009). Yeasts and wine flavour. In M. V. MorenoArribas, \& M. C. Polo (Eds.), Wine chemistry and biochemistry (pp. 313-392). New York: Springer Science+Business Media.

Verbelen, P. J., De Schutter, D. P., Delvaux, F., Verstrepen, K. J., \& Delvaux, F. R. (2006). Immobilized yeast cell systems for continuous fermentation applications. Biotechnology Letters, 28, 1515-1525.

Vilanova, M., Genisheva, Z., Bescansa, L., Masa, A., \& Oliveira, J. M. (2009). Volatile composition of wines from cvs. Blanco lexítimo, Agudelo and Serradelo (Vitis vinifera) grown in Betanzos (NW Spain). Journal of the Institute of Brewing, 115(1), 35-40.

Vilela, A., Schuller, D., Mendes-Faia, A., \& Côrte-Real, M. (2013). Reduction of volatile acidity of acidic wines by immobilized Saccharomyces cerevisiae cells. Applied Microbiology and Biotechnology, 97, 4991-5000.

Willaert, R., \& Nedovic, V. A. (2006). Primary beer fermentation by immobilised yeast - a review on flavour formation and control strategies. Journal of Chemical Technology and Biotechnology, 81, 1353-1367.

Yu, J., Zhang, X., \& Tan, T. (2007). An novel immobilization method of Saccharomyces cerevisiae to sorghum bagasse for ethanol production. Journal of Biotechnology, 129, 415-420. 